\title{
Effects of an enteric anaerobic bacterial culture supernatant and deoxycholate on intestinal calcium absorption and disaccharidase activity
}

\author{
K Walshe, M J Healy, A B J Speekenbrink, C T Keane, D G Weir, R R O'Moore
}

\begin{abstract}
Fifty two strains of anaerobic bacteria isolated from the upper gut of patients with small intestinal bacterial overgrowth were screened for phospholipase activity. Bacteroides melaninogenicus spp intermedius had the greatest activity. The effects of culture supernatants of this organism and deoxycholate on intestinal calcium absorption and disaccharidase activity were studied using a rat closed loop model. The supernatant decreased the in vitro uptake of calcium by $15 \%(\mathrm{p}<0.001)$. Deoxycholate reduced calcium uptake by $16 \%$ $(\mathbf{p}<0.001)$. Combined culture supernatant and deoxycholate reduced calcium uptake by $39 \%$ $(\mathbf{p}<0.001)$ suggesting a potentiation of supernatant activity by deoxycholate. Culture supernatant and deoxycholate, both alone and combined, significantly reduced lactase, sucrase, and maltase activity. Electron microscopic evidence showed degeneration of microvilli, disruption of mitochondrial structure, and swelling of the endoplasmic reticulum after exposure of the intestinal loops to the supernatant or deoxycholate.
\end{abstract}

The pathogenesis of contaminated small bowel syndrome remains controversial. It is characterised clinically by malabsorption of fats, fat soluble vitamins, and vitamin $\mathrm{B}_{12} .^{\prime}$ Protein calorie malnutrition ${ }^{2}$ and carbohydrate malabsorption $^{3}$ may also occur. The intestinal fat malabsorption in contaminated small bowel syndrome is usually attributed to bacterial deconjugation of bile salts leading to inadequate micelle formation. ${ }^{4}$ Several studies, however, have shown the presence of mucosal damage associated with contaminated small bowel syndrome. ${ }^{5-7}$ Various toxic products of bacterial metabolism have been suggested as aetiological agents. ${ }^{8}$

Several authors have suggested that bacterial overgrowth of the small intestine may contribute to calcium malabsorption and bone disease..$^{9-13}$ This is generally considered to be a secondary effect of vitamin D malabsorption, possibly by a direct destructive effect of intestinal bacteria on the vitamin ${ }^{10}{ }^{13}$ or a reduction of bile salt concentration necessary for its efficient absorption. ${ }^{13}$ In some instances the calcium malabsorption has been corrected by oral administration of synthetic vitamin D. ${ }^{12}$ Some patients, however, only respond to this treatment after antibiotic treatment. ${ }^{1213}$

Small intestinal bacterial overgrowth of unknown aetiology has also been described in chronic renal failure. ${ }^{14}$ Disturbances in calcium absorption and metabolism and resultant bone disorders are a major clinical problem in patients with this condition. ${ }^{15}$ It is generally thought that in patients with chronic renal failure the principal causal factor in the renal osteodystrophy is the inability of the kidney to convert 25 hydroxyvitamin $\mathrm{D}_{3}$ to its 1,25 dihydroxy form. ${ }^{16}$ Oral 1-hydroxyvitamin $\mathrm{D}_{3}$ has been shown to be effective in the treatment of some patients with renal osteodystrophy, ${ }^{17}$ although failure to respond to this form of treatment can occur. ${ }^{18}$ The reasons for this are unclear.

We have previously shown that the incidence of bacterial overgrowth in patients with chronic renal failure is approximately $30-40 \%,{ }^{19}$ and that cell free supernatants of many strains of Bacteroides melaninogenicus, an anaerobic bacterium commonly isolated from the upper small intestine of these patients, ${ }^{20}$ have phospholipase activity. ${ }^{21}$ These factors may play a role in the aetiology of calcium malabsorption and renal osteodystrophy in patients with chronic renal failure.

In this study a rat intestinal closed loop model was used to study the effect of Bacteroides melaninogenicus culture supernatant on the functional and morphological properties of the small intestine. The consequences of this on calcium absorption and mucosal enzyme activity are also examined. The effect of deoxycholate, an unconjugated bile salt that may be present in the upper small bowel of patients with contaminated small bowel syndrome ${ }^{8}$ on these processes was also investigated.

\section{Methods}

Unless otherwise stated all chemicals were 'Analar' grade and were supplied by $\mathrm{BDH}$ (Poole, England). Radiochemicals were supplied by Amersham Int (Bucks, England).

SCREENING OF ANAEROBIC BACTERIA FOR PHOSPHOLIPASE ACTIVITY

Fifty two strains of anaerobic bacteria were isolated from the upper small intestine of patients with chronic renal failure ${ }^{21}$ and screened for phospholipase activity (Table I). Stock phosphatidylcholine ( $99 \%$ pure: Sigma) was prepared by first dissolving it to $8.3 \% \mathrm{w} / \mathrm{v}$ in ethanol and diluting this in distilled water to $0.1 \% \mathrm{w} / \mathrm{v}$. To this was added $0.45 \mu \mathrm{Ci} / \mathrm{ml}$ of phosphatidylcholine- $\left(1-{ }^{14} \mathrm{C}\right)$-dipalmitoyl or phosphatidyl (U-1+C)-choline in ethanolic solution. Some $0.2 \mathrm{ml}$ of each of these was added to duplicate tubes containing $1.8 \mathrm{ml}$ of 24 hour cultures of the anaerobes to be screened. The 
TABLE I Strains of anaerobes screened for phosphatidylcholine degrading ability

\begin{tabular}{lc}
\hline Organism & No of isolates tested \\
\hline Bacteroides fragilis & 5 \\
Bacteroides vulgatus & 7 \\
Bacteroides distasonis & 2 \\
Bacteroides thetaiotamicron & 2 \\
Bacteroides melaninogenicus & 6 \\
ssp intermedius & 6 \\
ssp melaninogenicus & 2 \\
Bacteroides asaccharolyticus & 6 \\
Veillonella sp & 15 \\
Anaerobic Gram positive bacilli & 7 \\
\hline
\end{tabular}

tubes were incubated anaerobically at $37^{\circ} \mathrm{C}$ for two hours.

Altogether $20 \mu \mathrm{l}$ of the incubation mixture were chromatographed on $20 \times 20 \mathrm{~cm}$ thin layer plates coated with silica gel 60 (Merk Darmstadt $5721)$ in chloroform:methanol:water (65:25:4 $\mathrm{v} / \mathrm{v} / \mathrm{v}$ ). Authentic standards (choline, lysophosphatidylcholine, phosphatidylcholine, phosphatidylethanolamine, and phosphatidic acid, all 99\% pure and supplied by Sigma) were included on each plate. The activity in each track was assessed by dividing it into strips of $2 \mathrm{~cm}$. Each section was scraped into a scintillation vial, and a toluene based liquid scintillant added. Radioactivity was measured in a liquid scintillation spectrometer (Packard 1500).

\section{PREPARATION OF CULTURE SUPERNATANT OF} BACTEROIDES MELANINOGENICUS

The supernatant was prepared according to Speekenbrink. ${ }^{21}$ Bacteroides melaninogenicus ssp intermedius, isolated from the upper small intestine of patients with chronic renal failure, was grown anaerobically to early stationary phase in proteose peptone yeast extract broth containing $1 \%$ glucose. The broth was centrifuged at $20000 \mathrm{~g}$ for 20 minutes and the supernatant retained.

\section{SCREENING OF CULTURE SUPERNATANT FOR HAEMOLYTIC ACTIVITY}

Wells $4 \mathrm{~mm}$ in diameter were punched in plates consisting of $10 \mathrm{ml}$ of agar (Agar No 1: Oxoid)+ $0.85 \% \mathrm{NaCl}+10 \mathrm{mM}$ Tris $\mathrm{HCl}, \mathrm{pH} 7 \cdot 4$, and containing $1 \% \mathrm{w} / \mathrm{v}$ of freshly washed human red blood cells. Titrations were carried out by pipetting $10 \mu \mathrm{l}$ of serial dilutions of culture supernatant into the wells. The end point of titration was taken as the highest dilution at which a zone of haemolysis could be observed, and was reported as the reciprocal of this dilution. A haemolytic unit (HU) was defined as the quantity of haemolysin contained in the highest dilution giving visible haemolysis in well titrations.

\section{MUCINASE ACTIVITY OF CULTURE} SUPERNATANT

Preparation of ovomucin was performed using the modification of the method of Freter ${ }^{22}$ by Kusama and Craig. ${ }^{23}$ The $\mathrm{pH}$ of culture supernatant was adjusted to $7 \cdot 0$. To $1 \mathrm{ml}$ of supernatant at $0^{\circ} \mathrm{C}, 1 \mathrm{ml}$ of ovomucin was added, and the reaction mixture was incubated for two hours at $37^{\circ} \mathrm{C}$. The tubes were chilled to $0^{\circ} \mathrm{C}$ and $40 \mu \mathrm{l}$ of
$1 \% \mathrm{w} / \mathrm{v}$ cetyl tri-methyl ammonium bromide (Imperial Chemical Industries) was added. Absence of fibrous clot formation indicated the presence of ovomucinase activity.

\section{EFFECTS OF CULTURE SUPERNATANT ON INTESTINAL CALCIUM UPTAKE AND DISACCHARIDASE ACTIVITY}

Adult male Wistar rats weighing 200-250 g and maintained on standard rat chow were used in all studies. Before ligation of the small intestine the rats were starved but allowed water.

\section{TEST SOLUTIONS}

For the purpose of this study concentrated culture supernatant was used. This was prepared as follows: The $\mathrm{pH}$ of the supernatant was adjusted to 7.5 with $10 \mathrm{~N} \mathrm{NaOH}$ and filtered under negative pressure through a membrane with a pore size of $0.22 \mu \mathrm{m}$ (Sartorius, UK). The filtrate was concentrated approximately 100 fold over a membrane with a molecular weight exclusion of 10000 in an ultrafiltration cell using a PM 10 filter (Amicon UK). The undiluted supernatant had a haemolysin content of $15800 \mathrm{HU} / \mathrm{mg}$ protein.

The following test solutions were prepared in proteose peptone yeast extract broth:

(1) Proteose peptone yeast extract broth+ concentrated culture supernatant (adjusted to contain $1000 \mathrm{HU} / \mathrm{ml}$ ).

(2) Proteose peptone yeast extract broth + deoxycholate $(0.25 \mathrm{mM})$.

(3) Proteose peptone yeast extract broth + concentrated culture supernatant + deoxycholate (0.25 mM).

(4) Proteose peptone yeast extract broth+ denatured concentrated culture supernatant.

(5) Proteose peptone yeast extract broth only.

\section{INTESTINAL LIGATION}

Sections of the rat intestine were ligated to form closed loops according to the method of Lamabadusuriya et al. $^{24}$ Anaesthesia was induced by intraperitoneal injection of urethane (Sigma, Poole, England). Body temperature was maintained during operation by overhead lamps. The abdomen was shaved and opened along the midline by an incision approximately $4 \mathrm{~cm}$ in length. The stomach was located and working down about $15 \mathrm{~cm}$ from this point the section of the intestine was selected. A sterile catheter was inserted in a small hole cut in the antimesenteric surface of the small intestine and secured with a suture. After removal of residual faecal material in the loop, a similar tube was placed through a second opening $10-12 \mathrm{~cm}$ from the first to create a closed loop. Test solutions were infused into the ligated loops for two hours.

\section{CALCIUM UPTAKE}

Uptake of calcium was assessed by a tissue slice uptake technique using a modified Krebs Ringer bicarbonate buffer. ${ }^{25}$ The buffer was composed of $146 \mathrm{mM} \mathrm{NaCl}, 5.88 \mathrm{mM} \mathrm{KCl}, 0.164 \mathrm{mM}$ $\mathrm{MgSO}_{4}$ and $10 \mathrm{mM}$ glucose. A $1 \cdot 3 \%$ solution of 
TABLE II Phosphatidylcholine catabolism by anaerobes from the upper small intestine of patients with chronic renal failure

\begin{tabular}{|c|c|c|c|c|c|c|}
\hline \multirow[b]{2}{*}{ Organism } & \multirow[b]{2}{*}{ Strain(s) } & \multirow[b]{2}{*}{$\begin{array}{l}\text { PC } \\
\text { catabolism }\end{array}$} & \multirow[b]{2}{*}{$\begin{array}{l}\text { Position of } \\
{ }^{1+} \text { C-label }\end{array}$} & \multicolumn{3}{|c|}{$\%$ Labelled products after $2 h^{\star}$} \\
\hline & & & & Origint & Lyso-PC & $\begin{array}{l}\text { Fatty } \\
\text { acids }\end{array}$ \\
\hline Bacteroides sp & (16) & - & Acyl; choline & 0 & 0 & 0 \\
\hline Veillonella $\mathrm{sp}$ & (15) & - & Acyl; choline & 0 & 0 & 0 \\
\hline Bacteroides as accharolyticus & (6) & - & Acyl; choline & 0 & 0 & 0 \\
\hline Anaerobic Gram positive bacilli & $(7)$ & - & Acyl; choline & 0 & 0 & 0 \\
\hline $\begin{array}{l}\text { Bacteroides melaninogenicus } \\
\text { ssp melaninogenicus }\end{array}$ & 1 & + & $\begin{array}{l}\text { Acyl } \\
\text { Choline }\end{array}$ & $\begin{array}{r}0 \\
50\end{array}$ & $\begin{array}{l}2 \\
4\end{array}$ & $\begin{array}{r}49 \\
0\end{array}$ \\
\hline ssp melaninogenicus & 2 & + & $\begin{array}{l}\text { Acyl } \\
\text { Choline }\end{array}$ & $\begin{array}{r}0 \\
73\end{array}$ & $\begin{array}{l}3 \\
4\end{array}$ & $\begin{array}{r}38 \\
0\end{array}$ \\
\hline $\begin{array}{l}\text { Bacteroides melaninogenicus } \\
\text { ssp intermedius }\end{array}$ & 1 & + & $\begin{array}{l}\text { Acyl } \\
\text { Choline }\end{array}$ & $\begin{array}{r}0 \\
94\end{array}$ & $\begin{array}{l}2 \\
1\end{array}$ & $\begin{array}{r}36 \\
0\end{array}$ \\
\hline ssp intermedius & 2 & + & $\begin{array}{l}\text { Acyl } \\
\text { Choline }\end{array}$ & $\begin{array}{r}0 \\
52\end{array}$ & $\begin{array}{l}17 \\
33\end{array}$ & $\begin{array}{r}18 \\
0\end{array}$ \\
\hline ssp intermedius & 3 & + & $\begin{array}{l}\text { Acyl } \\
\text { Choline }\end{array}$ & $\begin{array}{r}0 \\
92\end{array}$ & $\begin{array}{l}5 \\
6\end{array}$ & $\begin{array}{r}43 \\
0\end{array}$ \\
\hline ssp intermedius & 4 & - & $\begin{array}{l}\text { Acyl } \\
\text { Choline }\end{array}$ & $\begin{array}{l}0 \\
0\end{array}$ & $\begin{array}{l}0 \\
0\end{array}$ & $\begin{array}{l}0 \\
0\end{array}$ \\
\hline ssp intermedius & 5 & + & $\begin{array}{l}\text { Acyl } \\
\text { Choline }\end{array}$ & $\begin{array}{r}0 \\
51\end{array}$ & $\begin{array}{l}2 \\
4\end{array}$ & $\begin{array}{r}49 \\
0\end{array}$ \\
\hline ssp intermedius & 6 & + & $\begin{array}{l}\text { Acyl } \\
\text { Choline }\end{array}$ & $\begin{array}{r}0 \\
91\end{array}$ & $\begin{array}{r}13 \\
3\end{array}$ & $\begin{array}{r}34 \\
0\end{array}$ \\
\hline
\end{tabular}

$\star \%$ of total radioactivity on plate. fOrigin of migration on TLC plate.

$\mathrm{PC}=$ phosphatidylcholine. lyso- $\mathrm{PC}=$ lysophosphatidylcholine.

For identification of Bacteroides strains not catabolising PC see Table I.

$\mathrm{NaHCO}_{3}$ was equilibrated with $\mathrm{CO}_{2}$ gas for 30 minutes before use. The two solutions were mixed, $1 \mathrm{ml} \mathrm{NaHCO}$ to $5 \mathrm{ml}$ of Krebs Ringer buffer, and the pH adjusted to $7 \cdot 4$ with $\mathrm{NaOH}$. The incubation medium for uptake studies was composed of $5 \mathrm{ml} \mathrm{Krebs} \mathrm{Ringer} \mathrm{bicarbonate}$ buffer containing $2 \mu \mathrm{Ci} / \mathrm{ml}^{45} \mathrm{CaCl}_{2}$ and $1.0 \mu \mathrm{m} / 1$ $\mathrm{CaCl}_{2} \cdot 0.5 \mu \mathrm{Ci}\left({ }^{57} \mathrm{Co}\right)$ cyanocobalamin in $50 \mathrm{mg}$ unlabelled cyanocobalamin was used as a nonabsorbable marker. ${ }^{25}$ To avoid adsorption of calcium ions onto glass, polyethylene tubes were used throughout (Sardstedt, UK).

\section{UPTAKE TECHNIQUE ${ }^{25}$}

After perfusion with the test solutions rats were killed by cervical dislocation. The closed loop was excised and cleared of infusion contents with isotonic saline. Tissue slices approximately $2 \mathrm{~mm}$ square and ranging in weight from 2-8 $\mathrm{mg}$ were cut from the intestine. Slices were moistened with deionised distilled water, randomised, and about 10 slices transferred to a preincubation buffer consisting of $5 \mathrm{ml}$ Krebs Ringer bicarbonate buffer. Slices were incubated for three minutes with continuous oxygenation by bubbling with $95 \% \mathrm{O}_{2}: 5 \% \mathrm{CO}_{2}$. Slices were then removed and transferred in duplicate to tubes containing uptake medium and incubated for 10 minutes at $37^{\circ} \mathrm{C}$ with continuous oxygenation.

TABLE III Effect of culture supernatant (CS) of Bacteroides melaninogenicus ssp intermedius and deoxycholate on calcium absorption

\begin{tabular}{|c|c|c|c|c|c|}
\hline Test solutions & $\begin{array}{l}\text { No tissue } \\
\text { slices } \\
\text { examined }\end{array}$ & No rats & $\begin{array}{l}\text { Calcium absorbed } \\
\text { (nmol/mg/10 min) }\end{array}$ & $p$ & $\begin{array}{l}\text { Calcium } \\
\text { absorbed } \\
(\%)\end{array}$ \\
\hline $\begin{array}{l}\text { PPY } \\
\text { PPY +CS } \\
\text { PPY + deoxycholate } \\
\text { PPY +CS + deoxycholate } \\
\text { PPY + denatured CS }\end{array}$ & $\begin{array}{r}134 \\
97 \\
84 \\
59 \\
47\end{array}$ & $\begin{array}{r}15 \\
11 \\
9 \\
7 \\
6\end{array}$ & $\begin{array}{l}0.907(0.032) \\
0.776(0.023) \\
0.761(0.027) \\
0.554(0.018) \\
0.902(0.007)\end{array}$ & $\begin{array}{l}<0.001 \\
<0.001 \\
<0.001 \\
\text { NS }\end{array}$ & $\begin{array}{l}85 \cdot 1 \\
83 \cdot 9 \\
61 \cdot 1 \\
99 \cdot 5\end{array}$ \\
\hline
\end{tabular}

Results expressed as mean (SEM). Test solutions are as described in methods. PPY=proteose peptone yeast extract broth. $p=$ significance values compared with PPY controls (Student's $t$ test for unpaired samples). $\mathrm{NS}=$ not significant. $\%$ calcium absorbed $=$ nmol calcium absorbed by each group divided by nmol absorbed by PPY controls $\times 100$
Uptake was terminated by removing the slices, blotting, and rinsing in ice cold Krebs Ringer buffer. Samples were reblotted and weighed. Slices were digested overnight in $0.1 \mathrm{M} \mathrm{HNO}_{3}$ and the contents neutralised with $0 \cdot 1 \mathrm{M} \mathrm{NaOH}$. Aliquots were counted using a Packard 5220 gamma counter to determine the ${ }^{57} \mathrm{Co}$ content. The ${ }^{45} \mathrm{Ca}$ was counted in a toluene:triton X-100 (2:1), PPO $(2.67 \mathrm{~g} / \mathrm{l})$ scintillation fluid. The uptake of calcium was calculated using the following formula:

$\frac{\mathrm{CPM} \text { tissue (total) }-\mathrm{dpm}{ }^{\mathrm{S}} \mathrm{Co} \times \% \text { counting efficiency }{ }^{+5} \mathrm{Ca} \times 1}{\frac{\text { Specific activity }{ }^{+5} \mathrm{Ca}}{\text { Tissue weight }(\mathrm{mg})}}$

Uptake was expressed as nmol calcium absorbed per $\mathrm{mg}$ tissue per 10 minutes.

\section{DISACCHARIDASE ACTIVITY}

Sections of intestinal loops not used for the calcium uptake study were everted with a glass rod and the absorptive layer removed with the reverse side of a clean scalpel blade. Some $4 \mathrm{ml}$ ice cold $5 \mathrm{mM}$ EDTA was added and the sample was homogenised for 30 seconds using a Waring blender. Mucosal disaccharidase activity was determined as described by Dahlqvist. ${ }^{26}$ One unit of enzyme activity is defined as the amount required to hydrolyse $1 \mathrm{mmol}$ of substrate per minute. Protein was determined by the method of Lowry et al. ${ }^{27}$

\section{ELECTRON MICROSCOPIC STUDIES}

Mucosa were fixed in $3 \%$ glutaraldehyde in $0.1 \mathrm{M}$ phosphate buffer, rinsed in the same buffer, post-fixed in $0.1 \%$ osmium tetroxide in $0.38 \mathrm{M}$ veronal acetate buffer, $\mathrm{pH} 7 \cdot 4$, and embedded in epon. Sections, stained with uranyl acetate and lead citrate, were examined in a Hitachi HU 12A electron microscope.

\section{STATISTICAL ANALYSIS}

The results are presented as mean (SEM). The significance of differences in mean values was determined by Student's $t$ test for unpaired samples.

\section{Results}

PHOSPHOLIPASE ACTIVITY OF ANAEROBIC

\section{ISOLATES}

Only Bacteroides melaninogenicus sp showed evidence of phospholipase activity with both strains of Bacteroides melaninogenicus ssp melaninogenicus and five of six strains of Bacteroides melaninogenicus ssp intermedius being capable of degrading phospholipid. When the labelled substrate was phosphatidylcholine$\left(1-{ }^{1+} \mathrm{C}\right)$-dipalmitoyl, two major products were detected that had thin layer chromatography mobilities comparable to authentic lysophosphatidylcholine and phospatidic acid. Two major products were also observed in the case of phosphatidyl (U-1+C)-choline degradationlysophosphatidylcholine and a compound that 

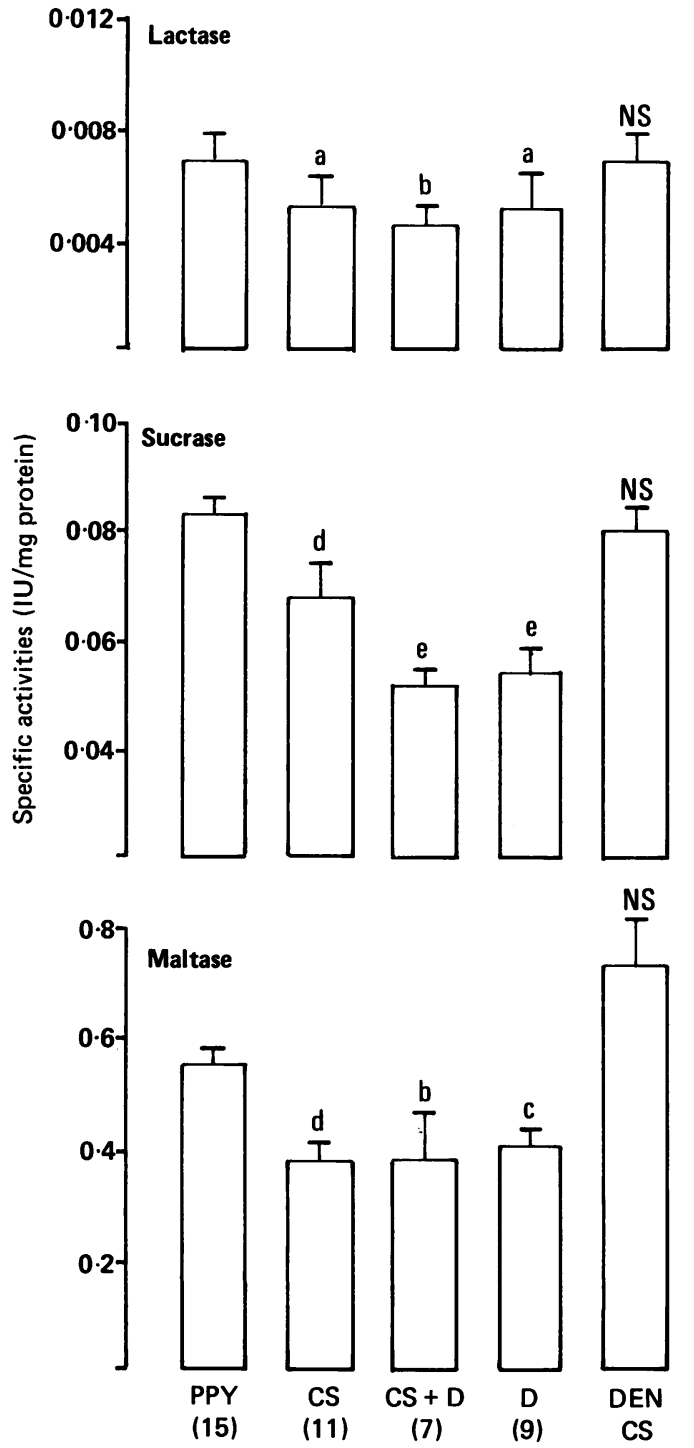

Figure 1: Effect of Bacteroides melaninogenicus spp intermedius culture supernatant and deoxycholate on intestinal disaccharidase activity. $P P Y=$ proteose peptone yeast culture medium only (control group), $C S=$ culture supernatant, $C S+D=$ culture supernatant + deoxycholate, $D=P P Y+$ deoxycholate, Den $C S=$ denatured culture supernatant. Significance values compared with control group: $a=p<0.05, b=p<0.025, c=p<0.005, d=p<0.0025$ $e=p<0 \cdot 001$. NS =not significant (Student's t test for unpaired samples). Figures in brackets represent number of rats studied in each group. Results presented as mean (SEM).

failed to move in the thin layer chromatography solvent system and was not identified. The results concerning phospholipase activity àre shown in Table II.

Bacteroides melaninogenicus ssp intermedius showed the greatest phospholipase activity and was selected for further investigation.

\section{SCREENING OF CULTURE SUPERNATANT FOR} HAEMOLYTIC ACTIVITY

Human, rabbit, and sheep red blood cells were used to examine the haemolytic activity of the culture supernatant. It lysed human better than sheep red blood cells. Although the reaction with rabbit was slightly better than that with human red blood cells, human cells were used throughout the study as they proved to be less fragile and more easily obtained.

\section{MUSINASE ACTIVITY}

The culture supernatants of three strains of Bacteroides melaninogenicus ssp intermedius were investigated for mucinase activity. Inhibition of fibrous clot formation was caused by one of the strains.

\section{CALCIUM UPTAKE}

Calcium uptake was assessed by in vitro exposure of approximately 10 tissue slices from each rat to ${ }^{45} \mathrm{Ca}$. There was a linear relation between tissue weight and calcium uptake. Table III shows the percentage decrease in calcium absorption when intestinal tissue was exposed to the test solutions. There was significantly lower calcium absorption after exposure of tissue to culture supernatant $(p<0.001)$. Deoxycholate reduced calcium absorption by a similar amount $(\mathrm{p}<0.001)$. The combination of toxin and deoxycholate resulted in a decrease in calcium absorption which was lower than the sum of either alone $(p<0.001)$. This suggests a potentiation of culture supernatant activity by deoxycholate. Boiling the supernatant for 10 minutes before exposure to the tissue resulted in normal calcium absorption.

\section{DISACCHARIDASE ACTIVITY}

The effect of toxin and deoxycholate on mucosal disaccharidases was monitored by measuring lactase, sucrase, and maltase activities in tissue homogenates (Fig 1). Both the culture supernatant and deoxycholate significantly reduced the activities of all three enzymes. The supernatant and deoxycholate combined also reduced the activity of the enzymes but the potentiation seen in the calcium absorption study was not observed in this instance. Boiled culture supernatant had no effect on enzyme activity.

\section{ELECTRON MICROSCOPY}

Electron microscopic examination of control tissue - that is, intestine exposed to proteose peptone yeast extract broth alone - showed a normal structural integrity of the mucosal surface (Fig 2). Exposure of the mucosa to culture supernatant resulted in distruption of the microvilli and swelling of both mitochondria and endoplasmic reticulum (Fig 3). Perfusion of intestinal loops with deoxycholate also caused extensive microvillous and intracellular damage to the enterocytes (Fig 4).

\section{Discussion}

In this study anaerobic broth cultures of Bacteroides melaninogenicus ssp intermedius were shown to contain phospholytic activity. The culture supernatants of these organisms were also shown to be haemolysin positive. One strain of Bacteroides melaninogenicus ssp intermedius which was phospholipase negative was also found to be haemolysin negative. Extracellular phospholipase activity in cultures of Bacteroides melaninogenicus has also been observed in a study of oral microorganisms. ${ }^{28}$ Other enzyme activi- 
Figure 2: Small intestinal enterocyte after exposure to proteose peptone yeast culture medium alone (control). Microvilli $(M v)$ and mitochondria $(M)$ look normal (original magnification $\times 24000)$.

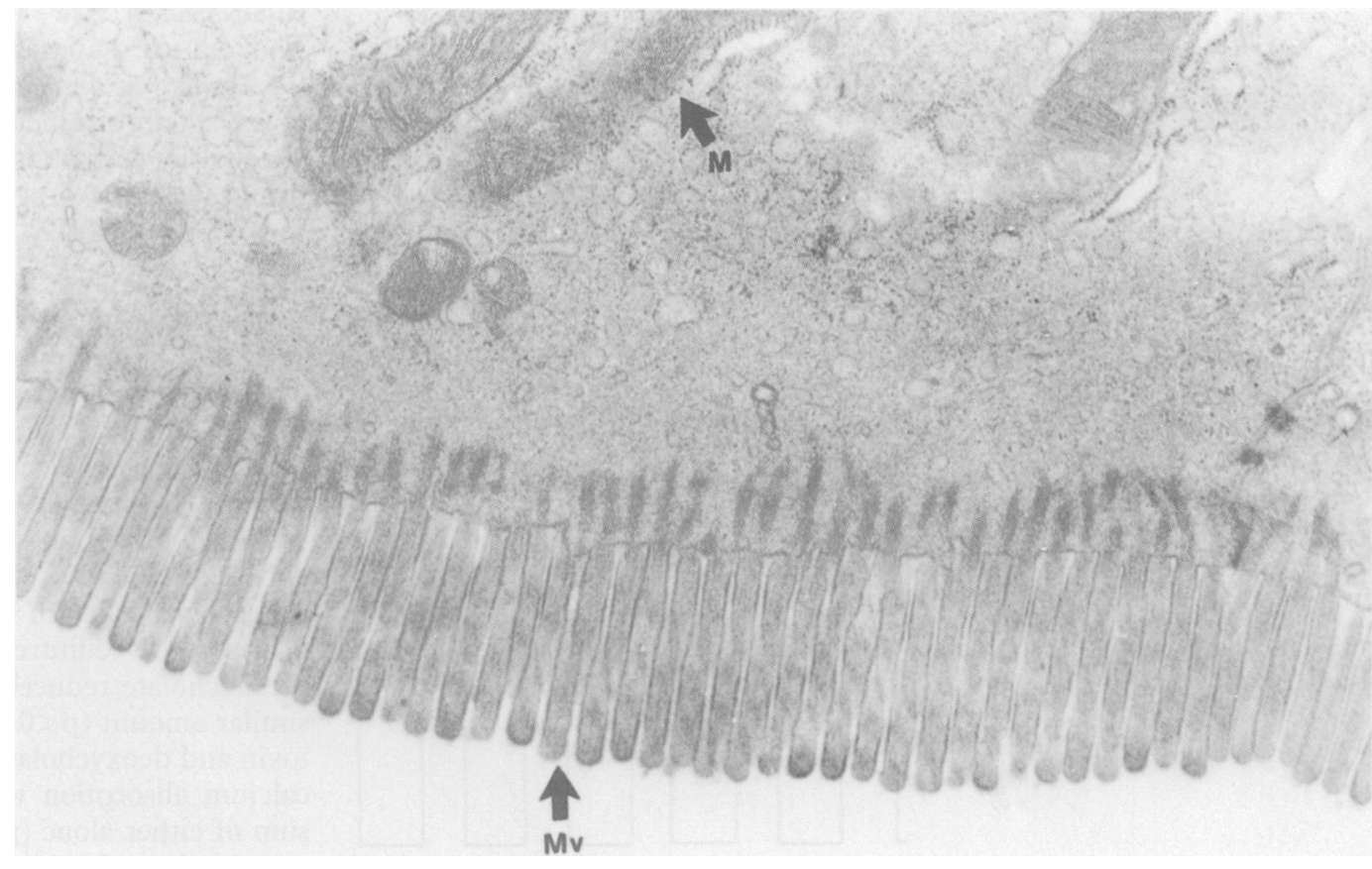

ties such as protease and collagenase were not assessed in this study.

Ovomucinase activity in Bacteroides melaninogenicus has not been reported previously. Degradation of gastrointestinal mucins through the action of bacterial 'mucinases' may occur. ${ }^{29}$ Some caution must be used, however, in the interpretation of mucinase assay results. Bile salts and lysophosphatidylcholine also affect the flow characteristics of mucus. ${ }^{30}$ The contribution of bacterial mucinase, in vivo, to mucus integrity is therefore uncertain.

Intestinal tissue damage in contaminated small bowel syndrome was once thought to be insignificant but is now considered to be an important cause of the malabsorption seen in this condition. Damage may range from loss of mucosal enzyme activity to ultrastructural enterocyte abnormalities. ${ }^{35}$ The cause of mucosal damage is not clear and several mechanisms have been proposed. Free bile acids ${ }^{31}$ or bacterial volatile fatty acids ${ }^{32}$ have been suggested as toxic agents. Bacterial mucinase activity in the upper small intestine could allow them access to the intestinal membrane. Thus bacterial enzymes may play a role in producing the malabsorption and the morphological changes observed in bacterial overgrowth, as suggested by Klipstein et al. ${ }^{33}$ In 1975 Gracey and his colleagues showed that cell free supernatants of bacteria from the jejunum of children with malnutrition and carbohydrate malabsorption produced abnormalities in monosaccharide transport when perfused through the rat small intestine. ${ }^{34}$ More recently bacterial proteases ${ }^{35}$. and glycosidases ${ }^{37}$ have been implicated in the intestinal abnormalities produced by small bowel bacterial overgrowth. It is still not certain
Figure 3: Damaged enterocyte after exposure to Bacteroides melaninogenicus $S P P$ intermedius culture supernatant. Disruption of the microvilli $(\mathrm{Mv})$ is seen with swelling of both the mitochondria $(M)$ and the endoplasmic reticulum (ER) (original magnification $\times 30000)$. 
Figure 4: Enterocytes in crypt region of intestine after exposure to deoxycholate. The large intracellular space (ICS) indicates extensive intracellular damage. Other enterocytes have both swollen mitochondria $(M)$ and endoplasmic reticulum (ER). Disruption of the microvilli $(M v)$ also occurred (original magnification $\times 7300)$

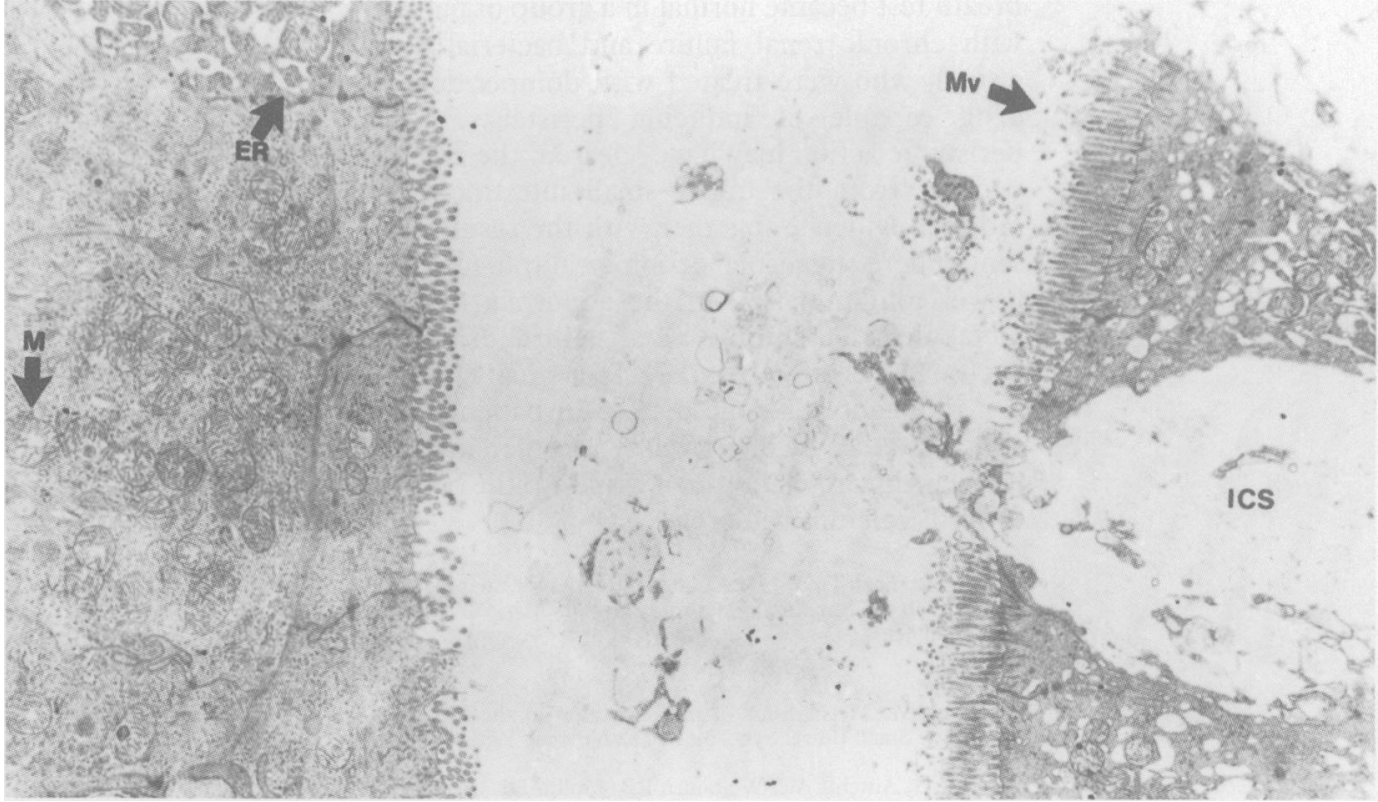

which bacterial species produce these toxins, although Bacteroides sp are often the predominant organism in overgrowth areas. ${ }^{38}{ }^{39} \mathrm{We}$ have previously reported a relation between the intestinal concentration of anaerobic bacteria and the degree of both malabsorption and mucosal damage. ${ }^{+0}$

Bacteroides melaninogenicus are common isolates in the upper small intestine of patients with contaminated small bowel syndrome and have been implicated in its pathology. ${ }^{+1}$ Normally it is an oral bacterium ${ }^{28}$ and is known to produce an extracellular protease..$^{+2}$ We are not aware that extracellular phospholipase activity produced by Bacteroides melaninogenicus ssp intermedius has been reported previously. Concentrated culture supernatant of these organisms produced mucosal damage to rat small intestinal tissue with concomitant reduction of mucosal calcium intake, reduced lipid absorption from the small intestine (Walshe et al, to be published), and a loss in membrane associated disaccharidase activity (Fig 1). The concentration of concentrated supernatant and the period of exposure to the small intestinal mucosa in this study may have been non-physiological. Exposure to the haemolysin/phospholipase in contaminated small bowel syndrome would, however, be chronic. The higher concentration used in these experiments may compensate for the brief exposure of the intestine to the culture supernatant.

Although disordered calcium metabolism is invariable in chronic renal failure, its pathogenesis is poorly understood. Along with already hypothesised causes such as secondary hyperparathyroidism, phosphate retention, diminished synthesis of 1-25 dihydroxyvitamin $\mathrm{D}_{3}$, skeletal resistance to the calcaemic action of parathyroid hormone, and aluminium accumulation in bone ${ }^{+3}$ decreased calcium absorption in patients with contaminated small bowel syndrome may also be a contributory factor in the onset of renal osteodystrophy. Previous animal studies have shown that calcium absorption occurs via membrane associated binding sites composed primarily of phospholipids or protein associated with lipid. ${ }^{+}$Destruction of these lipids by the hydrolytic action of a bacterial phospholipase may account for the decrease in calcium uptake observed in our study. Indeed it is also possible that intracellular calcium regulation may be disrupted by phospholytic degradation of phosphatidylinositol present in cell membranes. This phospholipid plays an important role in the intracellular regulation of free calcium concentration. ${ }^{15}$ The decrease in membrane associated protein suggests that some destruction of the membrane phospholipids has occurred. Bacterial proteases may also be implicated in the onset of membrane damage in contaminated small bowel syndrome. This was not examined in the present study.

In recent years synthetic forms of vitamin $D$, - that is, 1-hydroxyvitamin $\mathrm{D}_{3}$ and 1-25 dihydroxyvitamin $\mathrm{D}_{3}$ - have been used in attempts to reduce the development of renal osteodystrophy. ${ }^{16+7}$ It is not known if bacterial degradation of these vitamin $\mathrm{D}$ analogues occurs in patients with contaminated small bowel syndrome but should it occur a further disruption of calcium metabolism will take place.

Deoxycholate, an unconjugated bile salt and a known product of intestinal anaerobic bacterial metabolism, ${ }^{+8}$ is cytotoxic to upper small intestine mucosal cells ${ }^{49}$ and inhibits intracellular enzyme activity. ${ }^{50}$ In the present study deoxycholate caused a significant reduction in calcium absorption, a loss in disaccharidase activity, and damage to the mucosal enterocyte. The synergistic effect of deoxycholate on the culture supernatant is of interest since both bacterial enzymes and free bile salts are present in the upper small intestine of patients with bacterial overgrowth.

What is the importance of these findings to calcium metabolism in chronic renal failure? Should any of these patients have bacterial overgrowth of the small bowel they may be capable of producing a substance with phospholipase activity similar to the one described here. In an earlier study we showed that the calcium absorption coefficient and the ${ }^{1+} \mathrm{C}$ glycocholate 
breath test became normal in a group of patients with chronic renal failure and bacterial overgrowth who were treated with domperidone, a drug capable of inducing peristalsis. ${ }^{51}$ The peristaltic action may have 'cleared' the atypical bacteria from the upper small intestine. This indirect evidence together with the results presented here suggest an aetiological role for small bowel contamination in the abnormal calcium metabolism of chronic renal failure. Although bacterial overgrowth of the upper small intestine is a rare cause of bone disease in patients with contaminated small bowel syndrome, in those with chronic renal failure it could tip the balance towards calcium depletion.

We wish to thank Dr T J Peters and colleagues for their technical assistance in the calcium uptake study and Ms Marie O'Brien for secretarial help.

1 Gracey M. Mechanisms of malabsorption in the 'Contaminated Small Bowel Syndrome'. Die Nahrung 1984; 28: 65966.

2 Neale G, Antcliff AC, Welbourn RB, Mollin DL, Booth CC. Protein malnutrition after partial gastrectomy. $Q \mathcal{F}$ Med 1967; 36: 469-94.

3 Gracey M, Burke V, Oshin A, Barker J, Glasgow EF. Bacteria bile salts and intestinal monosaccharide malabsorption. Gut 1971; 12: 683-92.

4 Isaacs PET, Kim YS. The contaminated small bowel syndrome. Am $\mathcal{F}$ Med 1979; 67: 1049-57.

5 Gracey M, Papadimitriou J, Bower G. Ultrastructural changes in the small intestine of rats with self-filling blind loops. Gastroenterology 1974; 67: 646-51.

6 Toskes PP, Giannella RA, Jervis HR, Rout WR, Takeuchi A. Small intestinal mucosal injury in the experimental blind loop syndrome. Gastroenterology 1975; 68: 1193-203.

7 Menge H, Kohn R, Dietermann KH, Lorenz-Meyer H, Riecken EO, Robinson JWL. Structural and functional alterations in the mucosa of self-filling blind loops in rats. Clin Sci 1979; 56: 121-31.

8 King CE, Toskes PP. Small intestine bacterial overgrowth. Gastroenterology 1979; 76: 1035-55.

9 Cooke WT, Cox EV, Fone DJ, Meynell MJ, Gaddie R. The clinical and metabolic significance of jejunal diverticula. Gut 1963; 4: 115-31.

10 Gertner JM, Lilburn M, Domenech M. 25-Hydroxycholecalciferol absorption in steatorrhoea and post gastrectomy calciferol absorption in steatorrhoea and

11 Schjonsby H. Osteomalacia in the stagnant loop syndrome. Acta Med Scand 1977; 603 (suppl): 39-41.

12 Manicourt DH, Orloff S. Osteomalacia complicating a blind loop syndrome from congenital megaesophagus-megaduodenum. F Rheumatol 1979; 6:57-64.

13 Compston JE, Horton LW, Laker MF, et al. Treatment of bone disease after jejunoileal bypass for obesity with oral 1 hydroxyvitamin $\mathrm{D}_{3}$. Gut 1980; 21:669-74

14 Simenhoff ML, Saukkonen JJ, Burke JF, Wesson LG, Schaedler RW, Gordon SJ. Bacterial populations of the small intestine in uraemia. Nephron 1978; 22: 63-8.

15 Bricker NS, Slatopolsky E, Reiss E, Avioli LV. Calcium, phosphorus, and bone in renal disease and transplantation. phosphorus, and bone in renal dise

16 Bikle DD. Calcium absorption and vitamin D metabolism. Clin Gastroenterol 1983; 12: 379-94.

17 Coburn JW, Hartenbower DL, Brickman AS. Advances in vitamin D metabolism as they pertain to chronic renal disease. Am $\mathcal{F}$ Clin Nutr 1976; 29: 1283-99.

18 Ellis HA, Pierides AM, Feest TG, Ward MK, Kerr DNS Histopathology of renal oesteodystrophy with particula reference to the effects of $1 \alpha$-hydroxyvitamin $D_{3}$ in patients treated by long-term haemodialysis. Clin Endocrinol 1977 7 (suppl): $31 \mathrm{~S}-8 \mathrm{~S}$.

19 Speekenbrink ABJ, Little CL, Weir DG, et al. The role of anaerobes in chronic renal failure. Eur $\mathcal{F}$ Chem Antibiotic 1982; 2: 95-100.

20 Speekenbrink ABJ, Little CL, Keane CT, et al. Intestina bacterial flora in patients with chronic renal failure and
contaminated small bowel syndrome [Abstract]. Ir $\mathcal{Y} M e d S c i$ contaminated sma

21 Speenkenbrink ABJ. Microbiological and clinical aspects of dysbiotic enteric flora syndrome. PhD Thesis 1981; Dublin University, Trinity College Dublin.
22 Freter $\mathrm{R}$. The serological character of cholera vibrio mucinase f Infect Dis 1955; 97: 238-45.

23 Kusama H, Craig JP. Production of biologically active substances by two strains of Vibrio Cholerae. Infect Immun 1970 1: 80-7.

24 Lamabadusuriya SP, Guiraldes F, Harries JT. Influence of mixtures of taurocholate, fatty acids, and monoolein on the toxic effects of deoxycholate in rat jejunum in vivo. Gastroenterology 1975; 69: 463-9.

25 Duncombe VM, Watts RW, Peters TJ. In-vitro calcium uptake by jejunal biopsy specimens from patients with uptake by jejunal biopsy specimens from patient

26 Dahlqvist A. Method for assay of intestinal disaccharidases. Anal Biochem 1964; 7: 18-25.

27 Lowry OH, Rosebrough NJ, Farr AL, Randall RJ. Protein measurement with the Folin phenol reagent. $\mathcal{F}$ Biol Chem 1951; 193: 265-75

28 Bulkacz J, Newman MG, Socransky SS, Newbrun E, Scott DF. Phospholipase A activity of microorganisms from dental plaque. Microbios Lett 1979; 10: 79-88.

29 Hoskins LC. Bacterial degradation of gastrointestinal mucins II. Bacterial origin of fecal ABH (0) blood group antigen destroying enzymes. Gastroenterology 1968; 54: 218-24.

30 Martin GP, Marriott C, Kellaway IW. Direct effect of bile salts and phospholipids on the physical properties of mucus. Gut and phospholipids

31 Low-Beer TS, Schneider RE, Dobbins WO. Morphological changes of the small-intestinal mucosa of guinea pig and hamster following incubation in vitro and perfusion in vivo with unconjugated bile salts. Gut 1970; 11: 486-92.

32 Chernov AJ, Doe WF, Gompertz D. Intrajejunal volatile fatty acids in the stagnant loop syndrome. Gut 1972; 13: 103-6.

33 Klipstein FA, Holdeman LV, Corcino JJ, Moore WEC. Enterotoxigenic intestinal bacteria in tropical sprue. Ann Intern Med 1973; 79: 632-41.

34 Gracey M, Burke V, Thomas JA, Stone DE. Effect of microorganisms isolated from the upper gut of malnourished children on intestinal sugar absorption in vivo. Am $\mathcal{F}$ Clin Nutr 1975; 28: 841-5.

35 Jonas A, Krishnan C, Forstner C. The role of unconjugated bile salts and bacterial proteases as causes of mucosal injury in the contaminated bowel syndrome [Abstract]. Gastroenterology 1977; 72: 1076

36 Jonas A, Krishnan C, Forstner G. Pathogenesis of mucosal injury in the blind loop syndrome. Release of disaccharidases from brush border membranes by extracts of bacteria obtained from intestinal blind loops in rats. Gastroenterology 1978; 75: 791-5.

37 Prizont R. Mucin degradation in the blind loop syndrome [Abstract]. Gastroenterology 1978; 74: 1140.

38 Gorbach SL, Tabaqchali S. Bacteria, bile, and the small bowel. Gut 1969; 10: 963-72.

39 Tabaqchali S. The pathophysiological role of small intestinal bacterial flora. Scand f Gastroenterol 1970; [Suppl 6]: 139-63.

40 Little CL, Speekenbrink ABJ, Healy M, et al. Mechanisms for fat malabsorption in the contaminated small bowel syndrome [Abstract]. Gut 1981; 22: 876

41 Speenkenbrink ABJ, Little CL, O'Moore RR, et al. Lipid and bile salt metabolism of anaerobic bacteria from the upper small intestine and its relevance to chronic renal failure and contaminated small bowel syndrome. Soc Gen Microbiol $Q$ $1980 ; 7: 13-4$

42 Rudek W, Haque RU. Extracellular enzymes of the genus Bacteroides. I Clin Microbiol 1976; 4: 458-60.

43 Massry SG. Divalent ion metabolism and renal osteodystrophy. In: Massry SAG, Glassock RJ, eds. Textbook of nephrology Baltimore: Williams and Wilkins, 1983: 104-38.

44 Miller A, Li S-T, Bronner F. Characterisation of calcium binding to brush border membranes from rat duodenum. Biochem 7 1982; 208: 773-81.

45 Michell RH. Inositol phospholipids and cell surface receptor function. Biochim Biophys Acta 1975; 415: 81-147.

46 Catto GRD, MacCleod M, Pelc B, Kodicek E. l $\alpha$-hydroxycholecalciferol: a treatment for renal bone disease. BrMed $\mathcal{F}$ 1975; i: $12-4$.

47 Bordier P, Zingraff J, Gueris J, et al. The effect of $1 \alpha(\mathrm{OH}) \mathrm{D}_{3}$ and $1 \alpha, 25(\mathrm{OH})_{2} \mathrm{D}_{3}$ on the bone in patients with renal osteodystrophy. Am f Med 1978; 64: 101-7.

48 Dawson AM, Isselbacher KJ. Studies on lipid metabolism in the small intestine with observations on the role of bile salts. f Clin Invest $1960 ; 39: 730-40$.

49 Pope PC, Parkinson TM, Olson JA. Action of bile salts on the metabolism and transport of water soluble nutrients by perfused rat jejunum in vitro. Biochim Biophys Acta 1966; 130: $218-32$.

50 Dietschy JM. Effects of bile salts on intermediate metabolism of the intestinal mucosa. Fed Proc 1967; 26: 1589-98.

51 Robinson AR, Speekenbrink ABJ, O'Moore RR, Keane CT, Weir DG. Domperidone - an alternative therapy for contaminated small bowel syndrome? Ir f Med Sci 1984; 153: 358 